\title{
Introduction
}

During the past year, we have made considerable progress in elucidating the microbiological variables important in determining the relative success of bacteria in utilizing soil-sorbed contaminants. We had previously reported that two bacterial species, Pseudomonas putida (ATCC 17484) and an Alcaligenes sp. isolated from petroleum contaminated soil (and previously designated NP-Alk) differed markedly in their ability to utilize soii-sorbed napthalene. This result was based on a kinetic comparison of naphthalene mineralization in soil-containing and soil-free systems. The kinetic analysis led us to conclude that strain 17484 had direct access to naphthalene present in a labile sorbed state which promoted the rapid desorption of naphthalene from the non-labile phase. Conversely, both the rate and extent of naphthalene mineralization by strain NP-Alk suggested that this organism had access only to naphthalene in solution. Desorption was thus limited and the efficiency of total naphthalene removal from these soil slurries was poor. These conclusions were based on the average activities of cells in soil slurries without regard for the disposition of the organisms with respect to the sorbent. Since both organisms degrade naphthalene by apparently identical biochemical pathways, have similar enzyme kinetic properties, and are both motile, gram negative organisms, we undertook a series of investigations to gain a better understanding of what microbiological properties were important in bioavailability.

The first indication that the organisms differed in fundamental ways in their utilization of naphthalene in soil slurries came from a detailed examination of naphthalene mineralization kinetics over a range of soil:solution ratios. Figure 1a shows that for the Alcaligenes sp., initial naphthalene mineralization rates in both the absence and presence of soil were linearly related to the aqueous phase concentration. The almost identical slopes of the regressed data indicate that mineralization rates of the organism are strictly limited by sorption, and suggest further that the organisms behave in similar ways at all soil:solution ratios. The fact that all the rate data in soil slurries fell below the predicted rates indicated that the presence of soil in some way impeded the uptake of naphthalene or otherwise prevented it from being metabolized at the full enzymatic potential of the organism. Conversely, for $P$. putida, initial mineralization rates in soil slurries showed a distinct non-linsar relationship to the equilibrium aqueous phase naphthalene concentration with all rate data falling above the soil-free control line. These data confi, $m$ that sorbed naphthalene was available to the organism and indicated that the organisms responded to changing soil:solution ratios in a complex way, the basis of which may be related to its ability to utilize silil-sorbed naphthalene.

Based on previous reports of the importance of cell-sorbent interactions in determining the efficiency of sorbed substrate utilization (Kefford et al, 1981; Fletch.er, 1986: Griffith and Fletcher, 1992), it seemed logical to investigate the interactions of organisms with the soils in our systems. Furthermore, since others have reported that surfaces can directly and differentially influence the 
endogenous activities of bacteria (Jeffrey et al, 1988; Humphrey and Marshall, 1984; Hattori and Hattori, 1963; Hattori and Furusaka, 1960), we also attempted to evaluate this possibility with the two organisms. Finally, we undertook a series of experiments to determine if the physicochemical properties of the organisms alone could be related to their different abilities to utilize sorbed naphthalene. With these studies, our aim was to elucidate those traits of microorganisms which were related to their ability to utilize sorbed organic contaminants. This fundamental knowledge could allow us to develop a "profile" of a potentially useful or successful bioremediative organism in which limits on biodegradation of target contaminants imposed by sorption could be minimized.

\section{Cell-Sorbent Interactions}

Attachment of bacteria to the sorbent and other physiological and behavioral characteristics of cells might be expected to influence desorption kinetics and the rate and extent of sorbed substrate mineralization. Desorption from a sphere is described by Fick's first law (Koch, 1990):

$$
-d Q / d t=D A(d C / d x)
$$

Here, the diffusion rate $(-\mathrm{dQ} / \mathrm{dt})$ is a function of the diffusion coefficient $(D)$, the area of the diffusion barrier (A), and the concentration gradient across this barrier $(\mathrm{dC} / \mathrm{dx})$. Organisms with a low $\mathrm{K}_{\mathrm{m}}$ for a sorbed substrate, by establishing steep concentration gradients $(\mathrm{dC} / \mathrm{dx})$ at the sorbent surface, could facilitate desorptive diffusion. Attached bacteria, though not necessarily able to utilize sorbed substrates directly, might promote the desorption of substrate from a sorbent by shortening diffusion path lengths (dx). Attached organisms able to utilize sorbed substrates might experience a higher surface-localized concentration giving rise to enhanced mineralization rates and accelerated desorption rates.

The reversibility of attachment might also be important. Irreversible attachment could cause cells to become substrate-limited upon depletion of substrate in their immediate locale. Reversible attachment, on the other hand, may enable cells to migrate in search of new substrate sources. The latter, reversible attachment could be especially effective for an organism which is able to sense substrate concentration gradients and direct its motility toward regions of the sorbent harboring high substrate concentrations. Such chemotactic behavior may effectively increase (A) by creating many localized zones of substrate depletion on the sorbent surface, creating desorption "portals" for the outward diffusion of sorbed naphthalene. Soil crushing, which acts to increase A and decrease $\mathrm{dx}$, has been shown to increase the rate of NOC desorption in abiotic systems (Wu and Gschwend, 1986), and to increase the biodegradation rate of sorbed lindane in biological systems (Rijnaarts et al, 1991).

Attachment studies with the two organisms were conducted in two ways. Cells grown on naphthalene to the early stationary phase were washed, resuspended at a density of approximately $10^{9}$ cells $\mathrm{ml}^{-1}$ and added to sterile soil slurries (final cell density, $10^{7}$ cells $\mathrm{ml}-1$ ) in $25 \mathrm{ml}$ glass centrifuge tubes at various soil:solution ratios. Slurries were mixed by rotating for one hour and tubes were centrifuged ( $120 \times \mathrm{g}, 5 \mathrm{~min})$ to sediment coarse soil particles. The upper supernatant layer $(2 \mathrm{ml})$ was carefully siphoned by pipet, diluted twofold in 
phosphate-buffered saline (PBS) and immediately filtered ( $3 \mu \mathrm{m})$ into a sterile receiving tube. The filtrate was further diluted and plated in quadruplicate onto nutrient agar to estimate the number of unattached bacteria. Numbers were normalized to counts obtained from identically-treated soil-free controls to determine the fraction of free-living cells. In a modification of this method, cells were labeled by growth on 14C-labeled naphthalene. Rather than plate counts, the radioactivity of cells passing through the filters were then used to estimate relative numbers of unattached cells. Agreement between plate counts and radioactivty measurements were excellent.

Using this method with labeled cells, we observed a more or less linear dependence of attachment by both organisms on the soil concentration of the slurries. Figure 2 shows the soil concentration-dependent attachment of strains NP-Alk and 17484 to four soils of varying organic carbon contents. At low soil concentrations, NP-Alk showed a higher degree of attachment than 17484 while at higher soil concentrations, the reverse was true. For both organisms, the greatest attachment was observed for the low organic carbon Oshtemo soil. In general, strain 17484 showed a higher degree of attachment than NP-Alk. Less than $2 \%$ of the endogenous label was respired to ${ }^{14} \mathrm{CO}_{2}$ over the course of the assay ; radioactivity of slurry filtrates thus corresponded to unattached cells and not cellfree materials.

As with many attachment assays, this method does not distinguish between cells which are reversibly or irreversibly attached. We attempted to minimize the time and handling of supernatants prior to filtration to get an estimate of total attachment; however, it is possible that some detachment of reversibly adhered organisms occurred during sample manipulations. Attempts to estimate the number of irreversibly attached organisms by increasing the dilution factor prior to filtration were confounded by the fact that the organisms show differential attachment behavior as a function of dissolved organic carbon (a natural surfactant) in the slurries. Thus, progressive dilution of strain 17484 through $10^{-4}$ in PBS prior to filtration increased its attachment since attachment by this organism increases as the dissolved organic carbon concentration decreases (Guerin and Boyd, 1991). Artifical surfactants have also been reported to impede bacterial attachment (Erne et al, 1984). The opposite behavior was observed for strain NP-Alk; as the dilution factor increased (DOC decreased), attachment also decreased, suggesting that these organisms may have been only loosely associated with the soil.

A second method for estimating attachment, which was used in the 2,4-D bioavailability study of Ogram et al (1985), is to equilibrate radiolabeled cells in soil slurries for a fixed time period (usually about 1 hour) and to measure the radioactivity remaining in the cleared supernatant following settling of the soil (12 to 24 hours depending on the soil). Figure 3 shows a quite different picture of the attachment of the two organisms to soils using this method. In the Oshtemo slurries, significant removal of strain 17484 from supernatants occurred. Trends of increasing attachment at increasing soil:solution ratios were also reversed for some soils with both organisms. With motile, chemotactic organisms, the long settling periods allow for the detachment of previously attached cells, perhaps as an aerotactic response as cells become oxygen-limited in the sedimented soil. Conversely, the long settling times allow the irreversible attachment of cells previously associated in a reversible manner with the soils. A further drawback 
of this approach was that approximately 7 to $8 \%$ of the endogeous label was respired over the time required for estimating attachment by this method. These data show that the apparent attachment of both organisms is a dynamic process, subject to environmental conditions and behavioral characteristics of the organisms.

We reported previously (Guerin and boyd, 1991) that the two organisms showed different chemotactic behaviors toward naphthalene and to various components (dissolved organic carbon, clay minerals, whole soils) of naphthalenecontaining soil slurries. To assess the influence of chemotaxis on bioavailability, we compared the naphthalene mineralization kinetics in soil slurries by flagellated and deflagellated cells. The results, shown in Figure 4, indicated that the presence or absence of flagella significantly influenced the efficiency of sorbed naphthalene utilization. Deflagellated cells of strain 17484 were more efficient and those of strain NP-Alk were less efficient at mineralizing naphthalene in these slurries compared to their flagellated counterparts. This effect was most pronounced at low soil concentrations (higher equilibrium aqueous phase naphthalene concentrations).These results, however are somewhat difficult to interpret since flagella are organelles not only of motility (and therefore chemotaxis), but of attachment as well (Rogers, 1979; Sjoblad and Doetsch, 1982; Korber et al, 1989; DeFlaun et al, 1990).

We investigated the attachment characteristics of flagellated and deflagellated cells to the various soils to evaluate the role of flagella using the centrifugation-filtration method described above. As in the bioavailability assays described above, cells were deflagellated by pressurized passage 50 times through a small orifice ( $18 \mathrm{~g}$ hypodermic needle). Microscopic examination indicated a complete loss of motility by the cf:lls. Cells were then inoculated into soil slurries containing chloramphenicol $(50 \mathrm{\mu g} \mathrm{ml}-1)$ to inhibit resysnthesis of the flagella (Glagolev,1984). Figure 5 shows that flagella, as physical appendages, are relatively unimportant in the attachment of the polarly flagellated strain 17484 . Nearly identical patterns of attachment for flagellated and deflagellated cells were observed. For the peritrichously flagellated organism, Np-Alk, on the other hand, deflagellated cells showed a significantly higher rate of attachment to all but the high organic carbon Colwood soil. The flagella of this organism may impede attachment by not allowing a close enough approach of the cells to the soil surfaces. For both organisms, the extent of attachment by flagellated cells was lowered by the inclusion of chloramphenicol in the slurries. This suggests that some de novo synthesis of proteins may be involved in the normal attachment process by both organisms.

In summary, it has proven very difficult to assess the role of attachment in the efficiency of sorbed naphthalene utilization by the two organisms. This stems from ambiguities in what the various methods for estimating attachment are actually revealing, the dual roles of flagella as mediators of both attachment and motility, and our inability to assess the real time, reversible associations of the organisms with the soils. Differential cell growth at different soil:solution ratios is also a problem with assays which rely on plate counts to estimate attachment. This problem can be overcome by inclusion of chloramphenicol in soil slurries however, this antibiotic also influences attachment behavior. Thus, deflagellated NP-Alk attached more extensively to soils compared to its flagellated (and chloramphenicol-treated) counterparts, but the overall effect of its loss of motility 
was to lower naphthalene mineralization rates in soil slurries. Many of these methodological problems were pointed out in a recent review on bacteria-surface interactions (Fletcher, 1991).

We previously reported that strain 17484 is positively attracted to (and thus maintains its motility in) capillaries containing whole soil suspensions to a much greater extent than NP-Alk (Guerin and Boyd, 1991). Combined with its greater propensity to attach to soils and its ability to utilize sorbed naphthalene, the behavior of strain 17484 may be similar to the "motile attachment" described for $P$. fluorescens (Korber et al, 1989). Perhaps the more streamlined morphology of strain 17484 allows it to more closely approach soil surfaces where the sorbed naphthalene resides, and to avoid entanglement in the fibrillar soil organic matter network so that it maintains motility through soil slurries. NP-Alk, with its peritrichous flagella, may be prevented from attaching firmly to soils and utilizing naphthalene sorbed at the surface.

\section{Direct and Differential Surface Effects}

Solid surfaces have been reported to exert positive, negative and neutral effects on the activities of microorganisms (for recent reviews, see van Loosdrecht et al, 1990; Fletcher, 1991). Positive effects have been attributed, among other things, to the concentration of substrates sorbed to surfaces in nutrient-poor environments. Such sorption has also been reported to reduce the availability of substrates although the observed effects are inconsistent and appear to be related to the mechanism of sorbate-sorbent interaction (cation exchange, adsorption, hydrophobic binding, partition, etc.), the nature of the sorbent (granular activated carbon, clay minerals, hydrophobic vs. hydrophilic surfaces, etc.) and the characteristics of the test organisms (motility, hydrophobicity, mode and extent of attachment, etc.). Many of the reported observations are thus indirect effects inasmuch as the surfaces influence the disposition and accessibility of an exogenous substrate. We reported recently (Guerin and Boyd, 1992) that strains 17484 and NP-Alk differed in their ability to utilize sorbed naphthalene. While it was assumed that this was due to differential accessibility of the sorbed substrate to the two organisms, we did not rule out the possibility that the soil had a direct stimulatory effect on one organism and not the other. Direct stimulatory effects of surfaces on the endogenous activities of cells have been documented (Maigetter and Pfister, 1974; Humphrey and Marshall, 1984; Jeffrey and Paul, 1986) although the bases of these effects remain unknown. We therefore undertook a study to determine whether the two organism are influenced directly and/or differentially by surfaces which do not influence the distribution of naphthalene, i.e., are nonsorbing.

We have studied the chemotaxis of strains 17484 and NP-Alk to colloidal components of soil slurries and found that strain 17484 is positively chemotactic toward certain clay minerals (Figure 6), whereas NP-Alk is not. Furthermore, the magnitude of the chemotactic response and the clay concentration at which the maximum response occurred was clay mineral-specific. These observations led us to speculate that clay minerals may have a direct influence on the activity of strain 17484, possibly contributing to its more efficient utilization of napthalene in soil slurries. Since many clays (e.g., montmorillonite, hectorite) bear net negative charges, the strongly hydrated cations associated with them render the surfaces extremely hydrophilic. They are therefore poor sorbents for non-ionic organic 
compounds such as naphthalene. We undertook a study to evaluate the influence of clay minerals, as non-sorbing solids, on the naphthalene-degrading activity of the two organisms. Four clay minerals were chosen for these studies - negatively charged montmorillonite and hectorite, and the neutral aluminosilicates, phyrophillite and talc. All of these were reference materials obtained from the Clay Mineral Society. The clay mineral fractions were obtained by gravity settling of dispersed materials. They were sterilized by autoclaving and made homoionic by repeated washing in PBS before use. To establish the sorption behavior of the clays, we conducted naphthalene sorption isotherms. No detectable sorption to either montmorillonite or hectorite was observed. However, measurable sorption of naphthalene (5 to $25 \%$ ) to pyrophillite and talc was observed at clay concentrations of $2 \mathrm{mg} \mathrm{ml}^{-1}$ and initial napthalene concentrations which varied from approximately 15 to $1050 \mathrm{ng} \mathrm{ml-1}$.

Mineralization assays were conducted in which strains 17484 and NP-Alk were inoculated into vials containing naphthalene and one of the four clay minerals at a concentration of $2 \mathrm{mg} \mathrm{ml}-1$. The mineralization data were fitted to a three-parameter model (Guerin and Boyd, 1992) by non-linear regression analysis to obtain estimates of initial mineralization rates and extents of mineralization. Table 1 shows that for strain 17484, both the rate and extent of napthalene mineralization was enhanced in the presence of clay minerals, both those which showed no naphthalene sorption and those which showed minor sorption of naphthalene. Similar effects were observed in the presence of sand $\left(200 \mathrm{mg} \mathrm{ml}^{-1}\right.$, Ottawa sand standard, 20-30 mesh, Fisher), a solid which had zero sorptive capacity for naphthalene. Conversely, for strain NP-Alk, the presence of clay minerals (and sand) consistently inhibited both the rate and extent of napthalene mineralization. It thus appears that clay minerals have a direct stimulatory effect on the activity of strain 17484 and an inhibitory effect on naphthalene metabolism by NP-Alk. While the basis of these effects is rather puzzling, it is possible that surfaces may directly influence the activities of the organisms, and may partially explain the differential bioavailability of sorbed naphthalene observed. It is conceivable that organic colloids, too, may differentially influence the activities of the two organisms although assessing this possibility is complicated by the strong association of the substrate with the organic colloids.

Another possible explanation for the differential bioavailability of sorbed naphthalene relates to the physiology of the organisms. It is possible that introduction of stationary-phase cells into soil slurries causes a general or specific metabolic upshift in strain 17484 but not in NP-Alk. Rapid induction of specific naphthalene-degrading enzymes or an elevated metabolic activity in response to the soil slurry environment by strain 17484 may be responsible for its higher rate of naphthalene utilization in slurries than would be predicted by soilfree control rates. Such an induction or metabolic upshift would have to be extremely rapid, however, to influence measured initial mineralization rates. We will address this possibility in more detail below.

\section{Physicochemical Properties of Cells}

Recently, several models have been put forward which relate the kinetics of hydrophobic substrate utilization by bacteria to the physicochemical properties of the substrate (Banerjee et al, 1984; Parsons et al, 1987; Balaz et al, 1989). Biphasic relationships between the degradation kinetics of a homologous series of 
compounds by a single organism and the $\log \mathrm{K}_{\mathrm{ow}}$ (octanol-water partition coefficient) of the compounds have been observed with an inflection at a $\log \mathrm{K}_{\mathrm{ow}}$ of 2. Below this value, uptake is controlled by the membrane-water partition coefficient and above it uptake is controlled by solubility and diffusion across an aqueous boundary layer. We considered the possibilty that if uptake can be controlled by the physicochemical characteristics of the solute, it may also be sensitive to the physicochemical characteristics of the degrading organisms. Perhaps a more hydrophobic cell surface would allow for the more efficient uptake of naphthalene from the aqueous or sorbed phases. Cell surface hydrophobicity has been correlated with bacterial attachment to soils (Stenstrom, 1989).

The hydrophobicity of strains 17484 and NP-Alk were determined by the method of Dahlback et al (1981). Cells were labeled by growth on 14C-naphthalene to the early stationary phase. They were harvested, washed, and resuspended to a density of approximately $10^{9}$ cells $\mathrm{ml}^{-1}$ in PBS. A $1 \mathrm{ml}$ aliquot of the concentrated cell suspension was then applied to a column of Octyl-Sepharose CL-4B gel ( $3 \mathrm{ml}$ bed volume, Pharmacia) in a Pasteur pipet. Cells were eluted with $5 \times 2 \mathrm{ml}$ portions of PBS, each portion being collected in a scintillation vial containing 7.5 ml of counting cocktail. The counts of the eluted organisms (e) were summed and the number retained by the gel $(\mathrm{g})$ were determined by the difference between $\mathrm{e}$ and the counts obtained from a $1 \mathrm{ml}$ aliquot of the original suspension. Hydrophobicity indices were calculated as $\log (\mathrm{g} / \mathrm{e}$ ), with values below zero indicating hydrophilicity and values above zero indicating hydrophobicity. On three occasions over a two year period, strain 17484 yielded positive values $(0.122$, $0.155,0.493$ ) while NP.Alk consistently gave values indicative of a more hydrophilic cell surface $(-0.33,-0.28,0.194)$. The nonconstancy of these values reflects the dynamic nature of organisms maintained in laboratory culture for extended time periods. However, the consistently more hydrophobic character of strain 17484 offers a possible explanation for its ability to utilize sorbed naphthalene. The kinetics of mass transfer of naphthalene from the soil organic matter (which on the surface of a soil particle would be expected to be fairly hydrophilic in nature) to the cell surface would seem to be more rapid if the naphthalene was entering a more hydrophobic as opposed to a hydrophilic domain. The more hydrophobic surface and lack of peritrichous flagella in strain 17484 may also allow the cells to more closely approach the soil surface where attachment (reversible or irreversible) could occur. The soil-to-cell transfer of naphthalene is probably impossible to measure directly although fluorescence quenching methods have been applied to itudies of particle to membrane transfer of xenobiotics in model systems employing clay minerals as sorbents and fluorescently tagged artificial membranes as cell surrogates (Omann and Lakowicz, 1981). In soils, the natural fluorescence of soil organic matter would preclude such measurements.

We also studied the biosorption of napthalene to the two bacterial strains to determine if their capacity to sorb naphthalene was related to their differential ability to utilize it in soil slurries. The organisms were grown on naphthalene to the early stationary phase. They were then harvested, washed in PBS, and resuspended in a fraction of their original volume. Cells were killed by treatment with glutaraldehyde (final concentration, 5\%) for 1 hour, after which cells were repeatedly washed in PBS. Aliquots of cell suspensions were added to $25 \mathrm{ml}$ glass 
centrifuge tubes along with naphthalene solutions at concentrations ranging from approximately 20 to $5000 \mathrm{ng} \mathrm{ml-1}$. Suspensions were equilibrated with shaking overnight, the cells were removed by centrifugation, and the radioactivity remaining in the supernatant was taken as a measure of the equilibrium aqueous phase concentration. Aliquots of the original cell suspensions were analyzed for total organic carbon on a Dohrman DC-190 High Temperature TOC Analyzer and the concentration of sorbed naphthalene was determined from the difference between the initial and equilbrium naphthalene concentrations. Logs of the organic carbon-normalized partition coefficients $\left(\log \mathrm{K}_{\mathrm{oc}}\right)$ for naphthalene sorption to 17484 and NP-Alk were 2.96 and 2.94, respectively, indicating little difference between the two cell types in their capacity to bind naphthalene. These $\log \mathrm{K}_{\mathrm{oc}}$ vlaues are about midway between values determined for naphthalene sorption to soil (average of four soils, 2.64), and the $\log \mathrm{K}_{\mathrm{ow}} \mathrm{fc} \boldsymbol{\mathrm { c }}$ naphthalene of 3.35 , indicating that bacterial biomass is somewhat better than soil organic carbon as a partition medium for NOCs.

It shoula be mentioned here that the fact that the two organisms have nearly identical thermodynamic capacities for naphthalene sorption does not detract from the kinetic arguments made above on the basis of cell surface hydrophobicity. While the organic carbon of the two organisms is roughly equivalent in terms of its equilibrium sorption capacity for napthalene, this does not mean that the organisms may not differ considerably in the rate of transfer of naphthalene from another medium to the cell surfaces.

To summarize, we have identified several organism-specific properties which may be important in determining the relative efficiency of bacteria in utilizing sorbed contaminants. The "profile" for such an organism to be used in a bioremediation situation may include the following:

1. Low $\mathrm{K}_{\mathrm{m}}$ for substrate.

2. Motile.

3. Chemotactic toward the target contaminant(s).

4. Associates with soil particles in a reversible manner to avoid substrate limitation.

5. Hydrophobic cell surface to promote efficient soil-to-cell transfer of contaminants.

It may also be possible to modify the behavior and bioremediative efficiency of organisms by:

1. Adjustment of the dissolved organic carbon levels to promote or inhibit attachment.

2. Addition of clay minerals or other colloids to stimulate metabolism of endogenous and/or exogenous materials.

\section{New Research Initiatives}

In response to the revised goals of the Microbial Physiology/

Biodegradation subprogram of DOE's Subsurface Science Program, we have undertaken additional studies related to the stated objective of gaining a better understanding of the role of microbial adaptation in degradation of subsurface contaminants. Our successful approach for the study of the bioavailability of sorbed organic contaminants has utilized cells fully induced for the degradation of the target contaminants. In these experiments, we purposefully establish conditions where the activities of the organisms are strictly substrate-limited. It is 
conceivable that under certain bioremediation conditions, the organisms, whether indigenous to the contaminated aquifer or introduced to it, may instead be enzyme-limited. This problem may be particularly acute if contaminant sorption acts to decrease the aqueous phase contaminant concentration to a point where the induction of degradative enzymes is affected - here, biodegradation may be both substrate- and enzyme-limited. In the past year we have conducted research aimed at addressing two major questions:

1. What are the maintenance and induction characteristics of degradative enzymes? Is it possible to prepare cells for use in bioremediation which maintain high levels of enzyme activity?

2. How does sorption influence the bioavailability of contaminants to enzyme-limited bacteria? Are there threshold levels of dissolved contaminants resulting from sorption below which enzymes required for degradation will not be induced? Do nutrients $(\mathrm{N}, \mathrm{P})$ or additional carbon substrates influence the induction pattern?

As an index of enzyme activity, we used a whole cell, spectrophotometric assay for naphthalene dioxygenase (Shamsuzzaman and Barnsley, 1974) in conjunction with total cell protein determinations (Lowry et al, 1951) to obtain specific enzyme activity levels [ng naphthalene oxidzed ( $\mu$ g protein)-1 (min)-1] of cells under various growth and starvation regimens. Figure 7 shows the enzyme activities in cultures of strain 17484 and NP-Alk during stationary phase and under starvation conditions, following growth on napthalene. For the latter, cells were harvested in early stationary phase, washed in PBS, and resuspended to their original density in PBS. It is seen that activities in strain 17484 are higher intially (this organism also has a higher $V_{\max }$ for naphthalene utilization) and disappear less rapidly than those of NP-Alk. For both organisms, the enzyme appeared to be longer lived in starved vs. stationary phase cells. A first-order decay model was fit to the data to derive estimates of the first order decay constant, k;

$$
A=A_{0} e^{-k t}
$$

where $A$ is the activity at time, $t$, and $A_{0}$ is the activity at time zero. Enzyme halflives were then determined according to the following expression:

$$
t_{1 / 2}=0.693 / k
$$

Table 2 shows the naphthalene dioxygenase half lives for strains 17484 and NP. Alk under stationary and starvation conditions. It is seen that the half lives of enzymes under starvation conditions are 2.7 times longer and 5.3 times longer than those under stationary conditions for strain 17484 and NP-Alk, respectively. This finding has interesting implications. In bioremediation situations, it may be desirable to hold cells in a starvation condition prior to introducing them into the subsurface. This would greatly simplify handling considerations since starved cells with their low rates of endogenous metabolism could be more easily handled and transported than actively metabolizing cells. We are pursuing this question further to see if other hydrocarbon-degrading bacteria show similar enzyme maintenance characteristics under starvation conditions. 
To study the induction characteristics of the organisms, we monitored enzyme activities under different growth regimens for various time periods. It was found that the naphthalene dioxygenase activities of NP-Alk could be reduced to very low levels after extended incubation under either stationary or starvation conditions. However, for $\mathbf{1 7 4 8 4}$, fairly high basal levels of activity remained. For this organism, repeated subculturing in nutrient medium was required to attain low levels of enzyme for use in induction studies. To monitor the influence of naphthalene sorption on the induction of naphthalene dioxygenase activities, we inoculated vials containing a constant mass of naphthalene (in PBS) but varying soil:solution ratios (resulting in a range of equilibrium aqueous phase naphthalene concentrations) with cells containing various enzyme activities. The mineralization of naphthalene $\left({ }^{14} \mathrm{CO}_{2}\right.$ production) was monitored over time.

Figure 8 shows the naphthalene mineralization time courses for 17484 and NP-Alk at various initial enzyme activities (produced by growth under different conditions for various time periods prior to inoculation) in Colwood soil ( $5.5 \% \mathrm{OC}$ ) slurries. For both organisms, the kinetics of naphthalene mineralization in soil slurries were directly related to the initial enzyme activities of the inocula. For strain 17484, rapid and extensive mineralization of naphthalene was observed in starved ( $8 \mathrm{~d})$ cultures. Reductions in mineralization rates in proportion to the soil concentration (and equilibrium aqueous phase naphthalene concentration) were evident in stationary ( $22 \mathrm{~d}$ ) cultures but the extents of mineralization were all approximately equal at $23 \mathrm{~h}$. After 8 serial transfers in nutrient broth (20 d), further reductions in mineralization rates were observed. Here, complex mineralization sinetics related to shifts from substrate- to enzyme- and back to substrate-limitation were noted. The induction of naphthalene mineralization appeared to be very rapid for this organism with a greater extent of mineralization observed in samples with high soil concentrations and correspondingly high dissolved organic carbon concentrations. For NP-Alk, precipitous decreases in the kinetics of naphthalene mineralization were observed as the naphthalene dioxygenase activity declined from 1.02 ( $8 \mathrm{~d}$ starvation) to 0.22 (22 d stationary) to 0.08 ( $20 \mathrm{~d}$ nutrient broth) $\mathrm{ng}$ naphthalene ( $\mu \mathrm{g}$ protein)-1 (min)-1. As found with enzyme-sufficient cultures of this organism, both the rate and extent of naphthalene mineralization were limited by the equilibrium aqueous phase naphthalene concentrations. Cells were clearly enzyme-limited in the $22 \mathrm{~d}$ stationary cultures, where, up to $4 \mathrm{~h}$, the mineralization data for the soil-free control coincided with data for the $50 \mathrm{mg} \mathrm{ml}^{-1}$ soil slurry in which the equilbrium aqueous phase naphthalene concentration was less than one-half of that in the soil-free control. After $4 \mathrm{~h}$, the cultures in slurries were substrate-limited with an apparent induction or desorption of naphthalene occurring between 9 and $23 \mathrm{~h}$. In the nutrient broth grown cultures, the initial enzyme activity was very low and extended lags prior to the onset of naphthalene mineralization were observed. The length of the lag and the extent of mineralization were both inversely coirclated with the equilbrium aqueous phase naphthalene concentration. Apparently, the concentration of free naphthalene determined the kinetics of induction while the availability of alternate nutrients (soil concentration) determined the extent of induction and napthalene mineralization. The soil-free control showed the longest lag and lowest extent of mineralization over the $30 \mathrm{~h}$ time course of the experiment. A similarly low extent of mineralization was observed for 17484 and may be related to the absence of mineral and organic nutrients in PBS. 
To summarize, sorption clearly influences the kinetics of naphthalene mineralization in cells which are initially enzyme-limited for its degradation. The interplay of sorption-desorption reactions and enzyme induction give rise to complex mineralization patterns which are not easily amenable to modeling. The onset and extent of mineralization are also influenced by the presence or absence of alternative nutrient sources. This was confirmed in soil-free induction experiments in which the presence of soil extracts or mineral nutrients in addition to naphthalene caused higher levels of naphthalene dioxygenase induction than in naphthalene/PBS solutions. As in bioavailability studies with enzyme-sufficient cultures, major differences between two naphthalenedegrading organisms under enzyme-limited conditions were also observed, with regard to the kinetics of induction and the maintenance of degradative enzymes.

\section{Additional Accomplishments}

We have asserted that many of the inconsistencies in published reports regarding the bioavailability of sorbed organic compounds are the result not only of organism-specific differences, but of differences in the physicochemical aspects of solute sorbent interactions as well. Organics which sorb by fundamentally different mechanisms may be expected to be available to organisms to different degrees. We have applied the mineralization kinetics approach for assessing bioavailability developed under the aegis of our DOE funding to study the bioavailability of other classes of compounds in our laboratory. Under the auspices of an Air Force-funded project, we have isolated an unusual bacterium (strain 101S) able to use the cationic surfactant, hexadecyltrimethylammonium (HDTMA), as sole carbon and energy source. This compound sorbs to clay minerals by a cation exchange mechanism. We have found that the bioavailability of clay-bound HDTMA to strain 101S is dependent on clay mineral type and the location of the bound cation (surface vs. interlamellar). In fact, we have been able to use our bioavailability approach as a bioassay to gain insight about the avidity of clay-cation interactions under different reaction conditions (Mueller, Guerin and Boyd, unpublished results).

In research funded by the National Science Foundation through the Center for Microbial Ecology, we have also been using this approach to study 2,4-D bioavailability in soils. Using Flavobacterium strain FB-4 (Ogram et al, 1985), we have found that the bioavailability of 2,4-D is sorbent-dependent (Figure 9). This dependency is the result of the differential attachment behavior of strain FB-4 to different soils - as the fraction of attached urganisms increases, the efficiency of sorbed 2,4-D mineralization also increases (Kay, Guerin and Boyd, unpublished results).

We have recently developed a gas purge apparatus for studying the desorption kinetics of sorbed non-icnic organic compounds. Purge curves obtained from these studies allow determination of the equilibrium sorption coefficient, the fractional distribution of solute in labile and non-labile sorbed phases, and the first order rate constant for desorptive transfer from the non-labile to the labile phase. In initial studies with naphthalene, we have obtained desorption rate constants which are nearly identical to those determined by us (Guerin and Boyd, 1992) using a three-parameter coupled degradation-desorption model to fit naphthalene bioavailability data (Benzing and Boyd, unpublished results). In the coming year, we want to further study this correspondence between desorption 
rates measured in abiotic systems and those derived from modelling of mineralization data in biotic systems to establish the general utility of the model.

We originally proposed to study solubility as a physicochemical variable influencing bioavailability. We have isolated a phenanthrene-degrading bacterium from petroleum-contaminated soil which shows promise for these studies. This organism, a presumed Mycobacterium sp., grows robustly on phenanthrene and is easily maintained in laboratory culture. We have begun characterizing this organism and preliminary studies on its mode and kinetics and phenanthrene mineralization. We will soon employ it in bioavailability studies with the highly hydrophobic compound, phenanthrene.

\section{Publications and Presentations}

Over the last year, we have reported on our DOE-funded research at two national meetings;

Guerin, W.F., and S.A. Boyd. Role of bacterial attachment and chemotaxis in the efficiency of soil-sorbed naphthalene utilization," American Society for Microbiolgy, New Orleans, LA, May, 1992, Abstract No. N-22, p. 295.

Guerin, W.F., and S.A. F.d. Quantitative assessment of sorbed substrate bioavailability using a minerulization kinetics approach," invited paper, Soil Science Society of America, Minneapolis, MN, November, 1992.

Dr. Guerin has also presented our findings in invited seminars at;

Department of Biology, Marquette University, Milwaukee, WI.

Department of Agricultural Chemistry, Oregon State University, Corvallis, OR.

Department of Chemistry and Geochemistry, Colorado School of Mines, Golden, CO

Department of Environmental Toxicology. University of California, Santa Cruz, CA

Department of Environmental Safety, DOW Chemical Company, Midland, MI.

We have published the development and application of our mineralization kinetics approach for studying bioavailability, including the description of a "coupled degradation-desorption" model for analyzing bioavailability data. A paper describing our aging studies with napthalene has bcen accepted for publication as a book chapter, and two additional papers are in preparation. Full citations and tentative titles for these papers are:

Guerin, W.F., and S.A. Boyd. 1992. Differential bioavailability of soil-sorbed naphthalene to two bacterial species. Appl. Environ. Microbiol. 58:11421152.

Guerin, W.F., and S.A. Boyd. accepted. Bioavailability of soil-sorbed naphthalene to bacteria: influence of contaminant aging and soil organic carbon content. Soil Science Society of America, Special Publication. 
Guerin, W.F., and S.A. Boyd. in preparation. Bioavailability of soil-sorbed naphthalene: importance of physiological, behavioral and physicochemical characteristics of degrada e organisms.

Guerin, W.F., and S.A. Boyd. in preparation. Bioavailability of soil-sorbed naphthalene under enzyme-limited conditions.

\section{Research Objectives for 1993}

In the coming year, we will dedicate our research efforts in the following areas:

1. Assess the importance of contaminant solubility in determining bioavailability. We will make a detailed study of phenanthrene bioavailability using the organism described above and additional organisms differing in motility, hydrophobicity, and attachment properties from it. Since phenanthrene is about 30 times less soluble than naphthalene, we will be able to work with sorbents of much lower organic matter contents, including aquifer materials. This work will consist of batch and column biodegradation studies and will be complemented by abiotic studies on the sorption-desorption kinetics of phenanthrene (see original proposal).

2. Further investigations into the influence of contaminant sorption on induction of degradative enzymes in bacteria. We will investigate whether our observation of increased maintenance of degradative activity in starved microbial cells is a more general phenomenon, applying to other organisms which degrade other contaminants (toluene and phenanthrene). We will also further irvestigate the importance of mineral and organic nutrients in stimulating the induction process and assess the role of surfaces in the process. For example, if induction is a process of cell-to-cell transfer of genetic material encoding for the degradaion of a contaminant, such transfer may be facilitated by solid surfaces to which cells can attach.

3. Investigate the role of organic matter quality and quantity on bioavailability. With phenanthrene, we will study bioavailability in which the contaminant is bound to organic particle size fractions isolated from soil to test the concept of intraorganic matter diffusion as a constraint on desorption kinetics and bioavailability. We will also examine bioavailability of phenanthrene sorbed to soils in which the organic phase is non-particulate, i.e., where the organic matter exists as a monolayer coating mineral surfaces. We have collected additional soils and begun characterizing their organic matter to test the concept that the aromaticity of the soil organic matter modulates the binding of aromatic contaminants. With phenanthrene as a test contaminant we will conduct experiments to determine if organic matter quality influences bioavailability in otherwise similar systems (see original proposal).

4. We have initiated soil column studies aimed at studying the interactions of sorption and biodegradation in systems which more closely resemble natural situations. This work was outlined in detail in our original proposal.

5. Due to budget cutbacks in our second year funding, we will not pursue work with organic-modified (hexadecyltrimethylammonium-treated) soils. Such materials were originally to be included in both batch and column studies on bioavailability. 


\section{References}

Balaz, S., M. Wiese, M. Kansy, H. Chi, and J.K. Seydel. 1989. Model-based relationship between the microbial transformation rate of organic chemicals and the physicochemical properties. Chemosphere 19:1677-1692.

Banerjee, S., P.H. Howard, A.M. Rosenberg, A.E. Dombrowski, H. Sikka, and D.L. Tullis. 1984. Development of a general kinetic model for biodegradation and its application to chlorophenols and related compounds. Environ. Sci. Technol. 18:416-422.

Dahlback, B., M. Hermansson, S. Kjelleberg, and B. Norkrans. 1981. the hydrophobicity of bacteria. An important factor in their initial adhesion at the airwater interface. Arch. Microbiol. 128:267-270.

DeFlaun, M.F., A.S. Tanzer, A.L. McAteer, B. Marshall, and S.B vvy. 1990. Development of an adhesion assay and characterization of an adricsion-deficient mutant of Pseudomonas fluorescens. Appl. Environ. Microbiol. 56:112-119.

Erne, A.M., R.G. Werner, and R. Reifenrath. 1984. Inhibition of bacterial adhesion by an artificial surfactant. FEMS Microbiol. Lett. 23:205-209.

Fletcher, M. 1986. Measurement of glucose utilization by Pseudomonas fluorescens that are free-living and that are attached to surfaces. Appl. Environ. Microbiol. 52:672-676.

Fletcher, M. 1991. The physiological activity of bacteria attached to solid surfaces. Adv. Microb. Physiol. 32:53-85.

Glagolev, A.N. 1984. Motility and taxis in prokaryotes. Soviet Scientific Reviews Supplement Series. Physicochemical Biology, Volume 3. Harwood Academic Publishers GmbH, Zurich.

Griffith, P.C., and M. Fletcher. 1991. Hydrolysis of protein and model dipeptide substrates by attached and nonattached marine Pseudomonas sp. strain NCIMB 2021. Appl. Environ. Microbiol. 57:2186-2191.

Guerin, W.F., and S.A. Boyd. DOE Progress Report, December, 1991.

Guerin, W.F., and S.A. Boyd. 1992. Differential bioavailability of soil-sorbed naphthalene to two bacterial species. Appl. Environ. Microbiol. 58:1142-1152.

Hattori, T., and C. Furusaka. 1960. Chemical activities of $E$. coli adsorbed pm a resin. J. Biochem. 48:831-837.

Hattori, R., and T. Hattori. 1963. Effect of a liquid-solid interface on the life of micro-organisms. Ecol. Rev. 16:63-70. 
Humphrey, B.A., and K.C. Marshall. 1984. the triggering effect of surfaces and surfactants on heat output, oxygen consumption and size reduction of a starving marine Vibrio. Arch. Microbiol. 140:166-170.

Jeffrey, W.H., and J.H. Paul. 1986. Activity of attached and free-living Vibrio sp. as measured by thymidine incorporation, $p$-iodonitrotetrazolium reduction, and ATP/DNA ratios. Appl. Environ. Microbiol. 51:150-156.

Kaffiord, B., S. Kjelleberg, ang K.C. Marshall. 1982. Bacterial scavenging: utilization of fatty acids localized at a soild-liquid interface. Arch. Microbiol. 133:25; $;-260$.

Koch, A.L. 1990. Diffusion. The crucial process in many aspects of the biology of bacteria. Adv. Microb. Ecol. 1137-70.

Korber, D.R., J.R. Lawrence, B. Sutton, and D.E. Caldwell. 1989. Effect of laminar flow velocity on th. kinetics of surface recolonization by Mot+ and Mot-

Pseudomonas fluorescens. Microb. Ecol. 18:1-19.

Lowry, O.H., N.J. Rosebrough, A.L. Farr, and R.J. Randall. 1951. Protein measurement with the Folin phenol reagent. J. Biol. Chem. 193:265-275.

Maigetter, R.Z., and R.M. Pfister. 1974. A mixed bacterial population in a continuous culture with and without kaolinite. Can. J. Microbiol. 21:173-180.

Ogram, A.V., R.E. Jessup, L.T. Ou, and P.S.C. Rao. 1985. Effects of sorption on biological degradation rates of [2,4-dichlorophenoxyacetic] acid in soils. Appl. Environ. Microbiol. 49582-587.

Omann, G.M., and J.R. Lakowicz. 1981. Transfer of chlorinated hydrocarbon insecticides and polychlorinated biphenyls from particles to membranes studied by quenching of fluorescence. Pesticide Biochem. Physiol. 16:231-248.

Parsons, J.R., A. Opperhuizen, and O. Hutzinger. 1987. Influence of membrane permeation on biodegradation kinetics of hydrophobic compounds. Chemosphere 16:1361-1370.

Rijnaarts, H.H.M., A. Bachmann, J.C. Jumelet, and A.J.B. Zehnder. 1990. Effect of desorption and intraparticle mass transfer on the aerobic biomineralization of ahexachlorocyclohexane in a contaminated calcareous soil. Envion. Sci. Technol. 24:1349-1354.

Rogers, J.H. 1979. Adhesion of microorganisms to surfaces: some general considerations of the role of the envelope, p. 29-55. In D.C. Ellwood, J. Melling, and P. Rutter (ed.), Adhesion of microorganisms to surfaces. Academic Press, London.

Shamsuzzaman, K.M., and E.A. Barnsley. 1974. The regulation of naphthalene oxygenase in pseudomonads. J. Gen. Microbiol. 83165-170. 
Sjoblad, R.D., and R.N. Doetsch. 1982. Adsorption of polarly flagellated bacteria to surtaces. Curr. Microbiol. 7:191-194.

Stenstrom, T.A. 1989. Bacterial hydrophobicity, an overall parameter for the measurement of adhesion potential to soil particles. Appl. Environ. Microbiol. 55:142-147.

van Loosdrecht, M.C.M., J. Lyklema, W. Norde, and A.J.B. Zehnder. 1990. Influence of interfaces on microbial activity. Microbiol. Rev. 54:75-87.

Wu, S.C., and P.M. Gschwend. 1986. Sorption kinetics of hydrophobic organic compounds to natural sediments and soils. Environ. Sci. Technol. 20:717-725.

\section{DISCLAIMER}

This report was prepared as an account of work sponsored by an agency of the United States Government. Neither the United States Government nor any agency thereof, nor any of their employees, makes any warranty, express or implied, or assumes any legal liability or responsibility for the accuracy, completeness, or usefulness of any information, apparatus, product, or process disclosed, or represents that its use would not infringe privately owned rights. Reference herein to any specific commercial product, process, or service by trade name, trademark, manufacturer, or otherwise does not necessarily constitute or imply its endorsement, recommendation, or favoring by the United States Government or any agency thereof. The views and opinions of authors expressed herein do not necessarily state or reflect those of the United States Government or any agency thereof. 


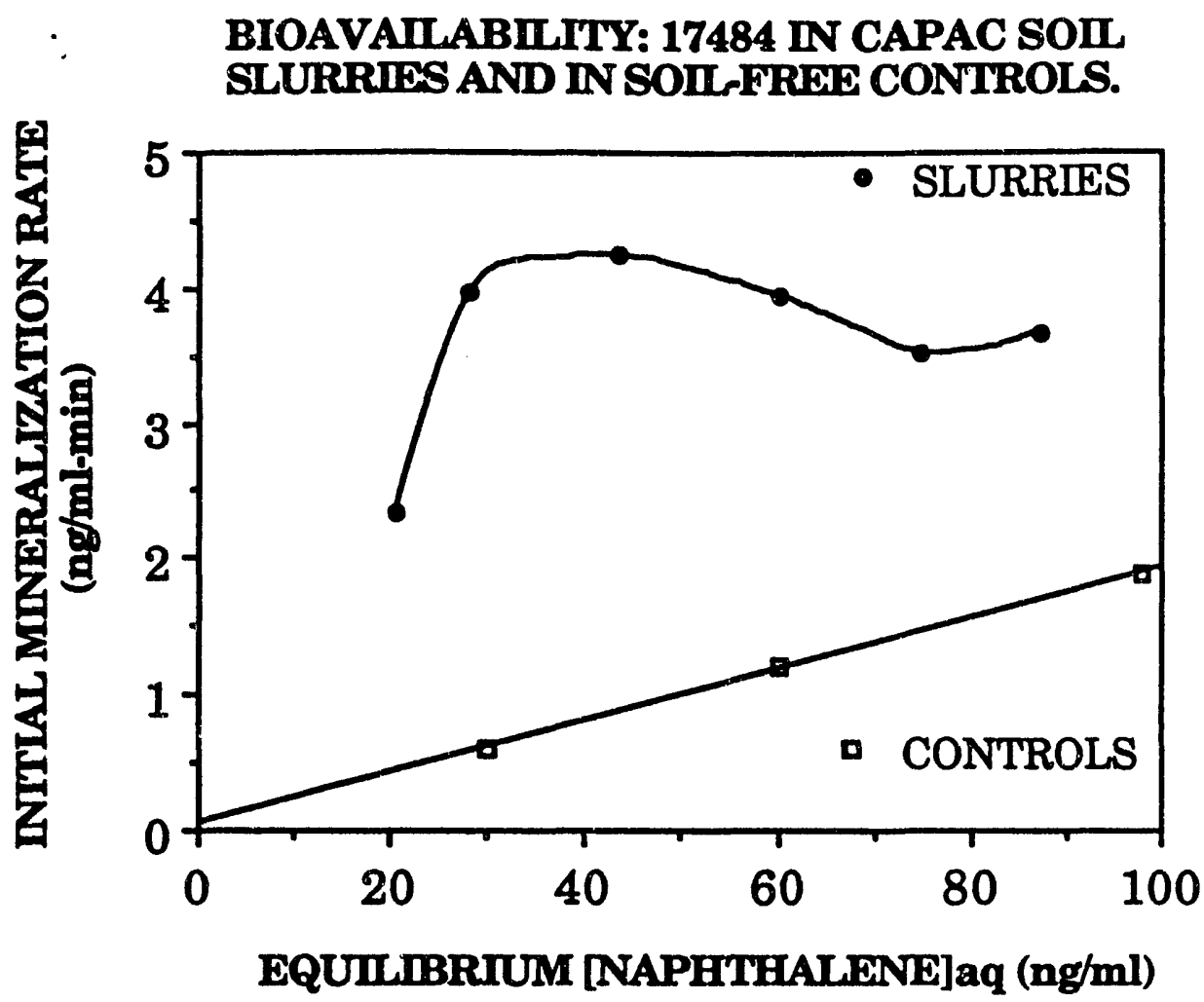

\section{BIOAVAILABILITY: NP-Alk IN COLWOOD SOK SLURRIES AND IN SOILFREE CONTROLS.}

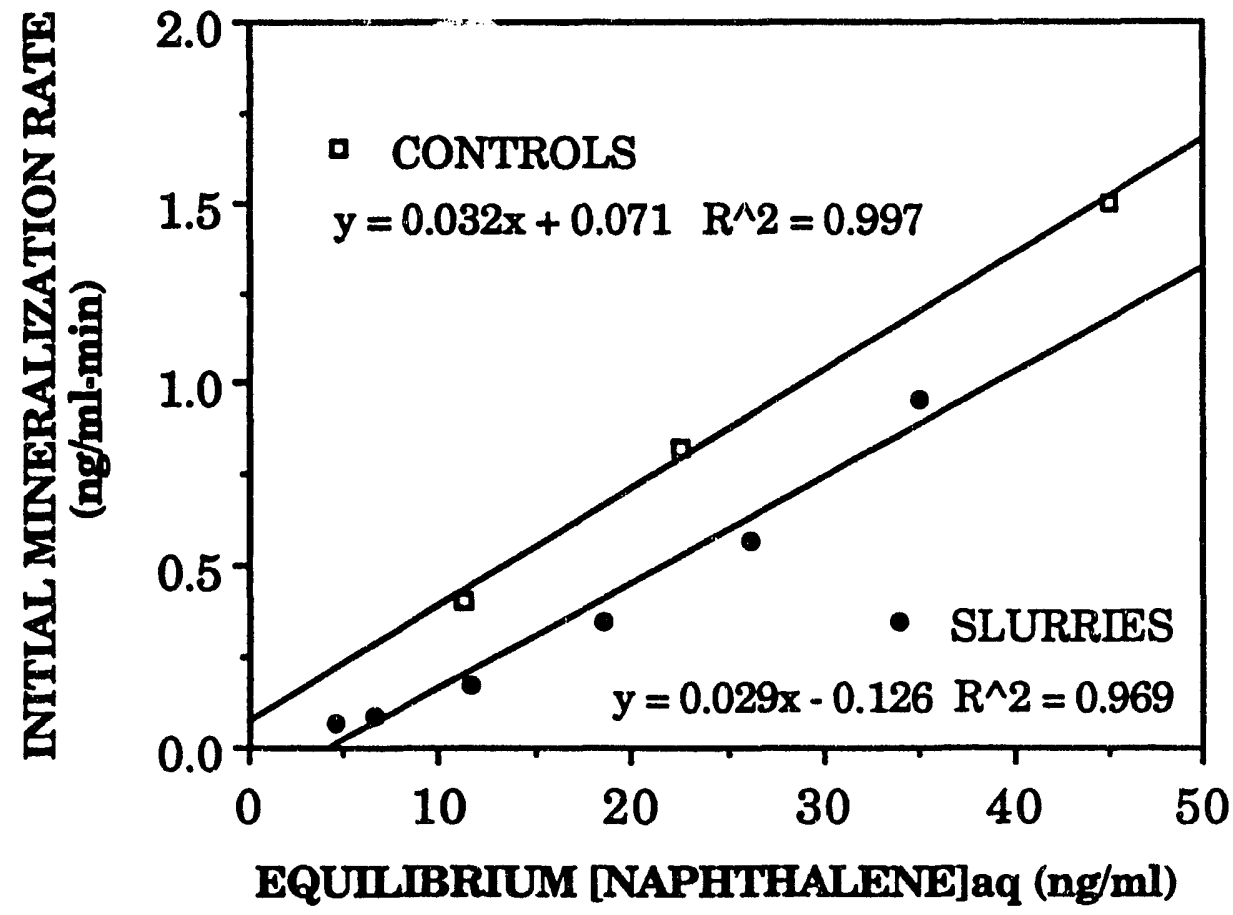

Figure 1. Influence of sorption on the rate of naphthalene mineralization in soil slurries by strains 17484 (top panel) and NP-Alk (bottom pane1). Rates in slurries which fall on or below the control line indicate that sorbed naphthalene is unavailable, while rates falling above the line indicate that sorbed naphthalene is directly available to the bacteria. 


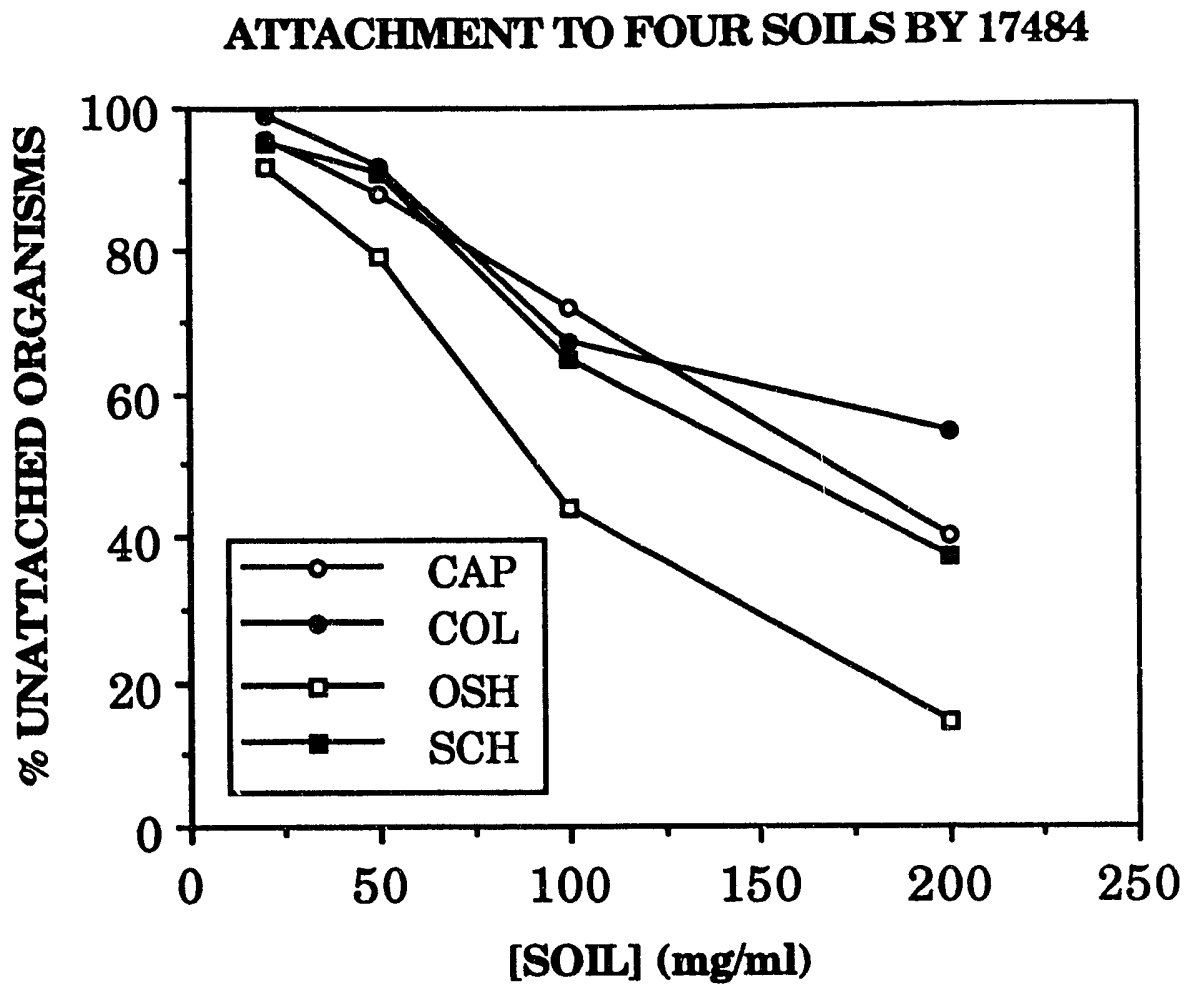

ATTACHMENT TO FOUR SOIS BY NP-Alk

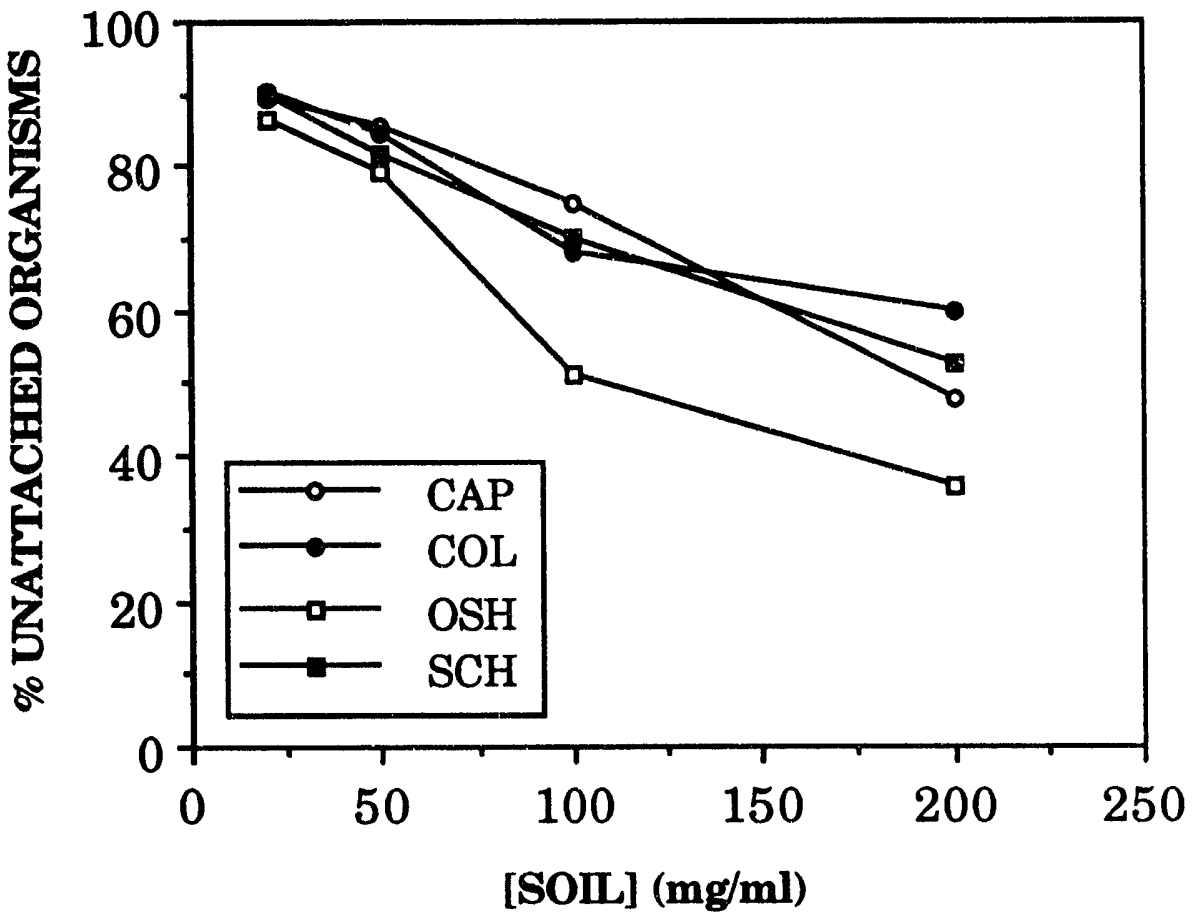

Figure 2. Attachment of strains 17484 (top panel) and NP-Alk (bottom pane1) to four soils as a function of soil concentration. Organic carbon (OC) contents of the soils are: Capac, $3.46 \%$; Colwood, $5.36 \%$; Oshtemo, $0.76 \%$; Schoolcraft, $1.84 \%$. 


\section{ATTAHCMENT OF 17484 TO FOUR SOILS BY SETTLING}

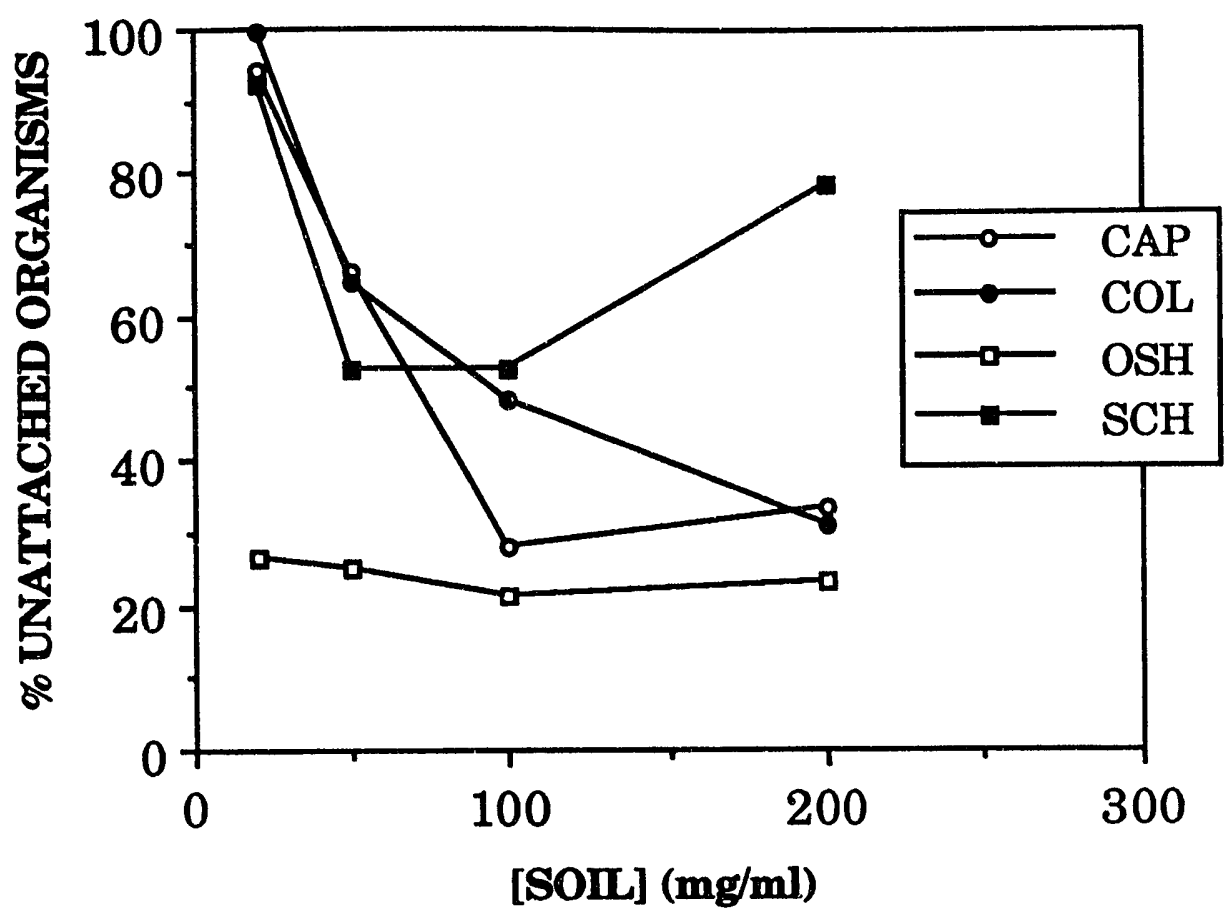

\section{ATTACHMENT OF NP-Alk TO FOUR SOISS BY SETTLING}

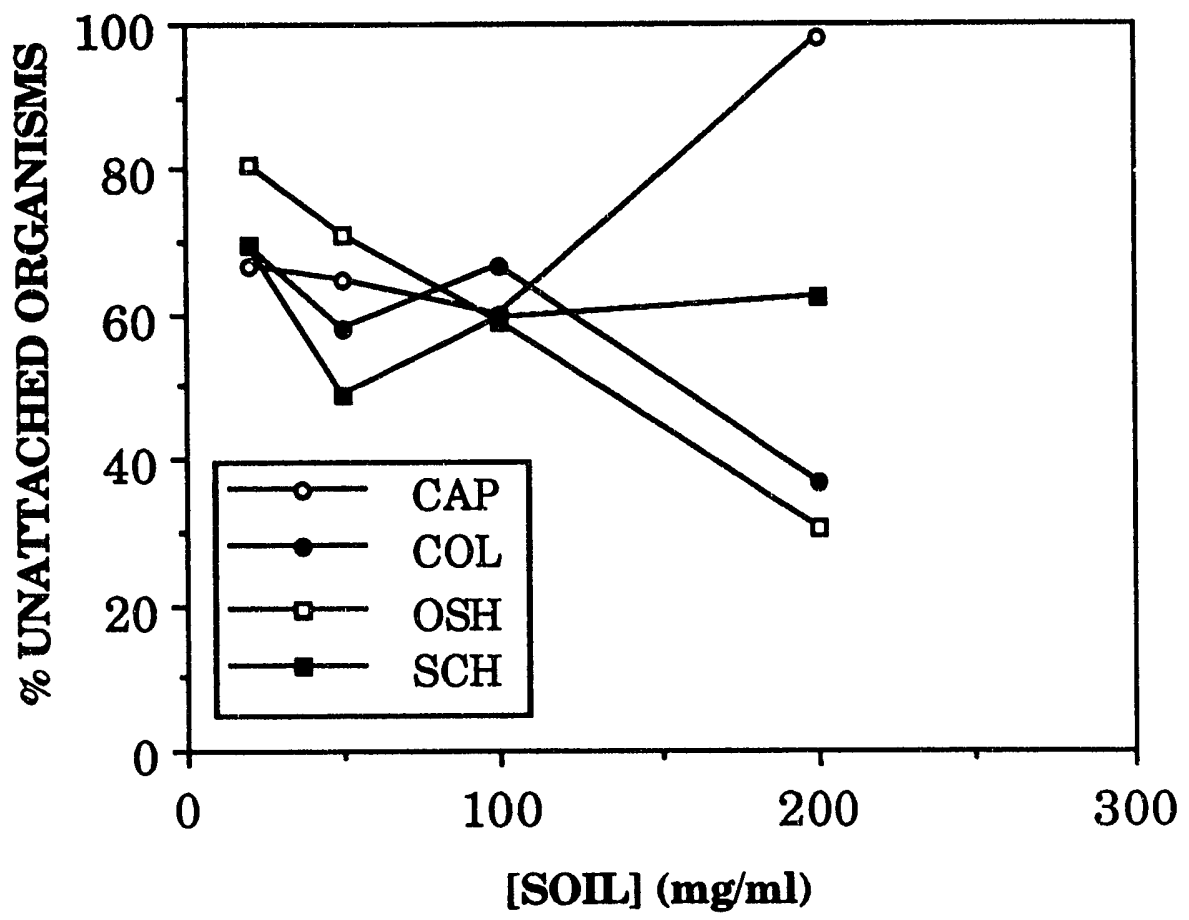

Figure 3. Attachment of strains 17484 (top pane1) and NP-Alk (bottom panel) to four soils as a function of soil concentration. Attachment was estimated by measuring the radioactivity of labeled cells in cleared supernatants following settling of soil solids. 

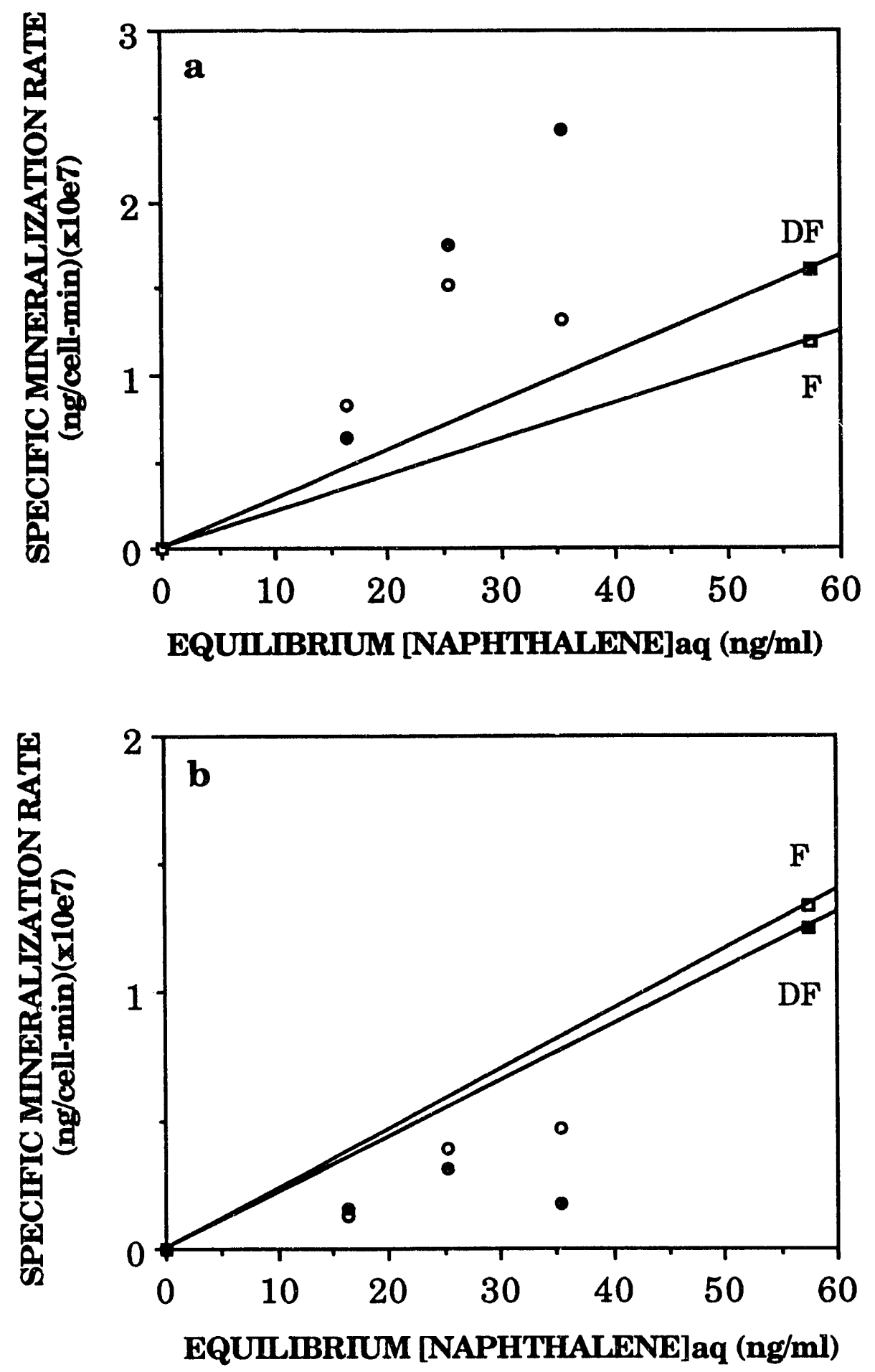

Figure 4. Influence of sorption on the rate of naphthalene mineralization by flagellated (F, open symbols) and deflagellated (DF, solid symbols) cells of strains 17484 (a) and NP-Alk (b). Boxes are rates measured in soil-free controls, circles are rates measured in soil slurries. 

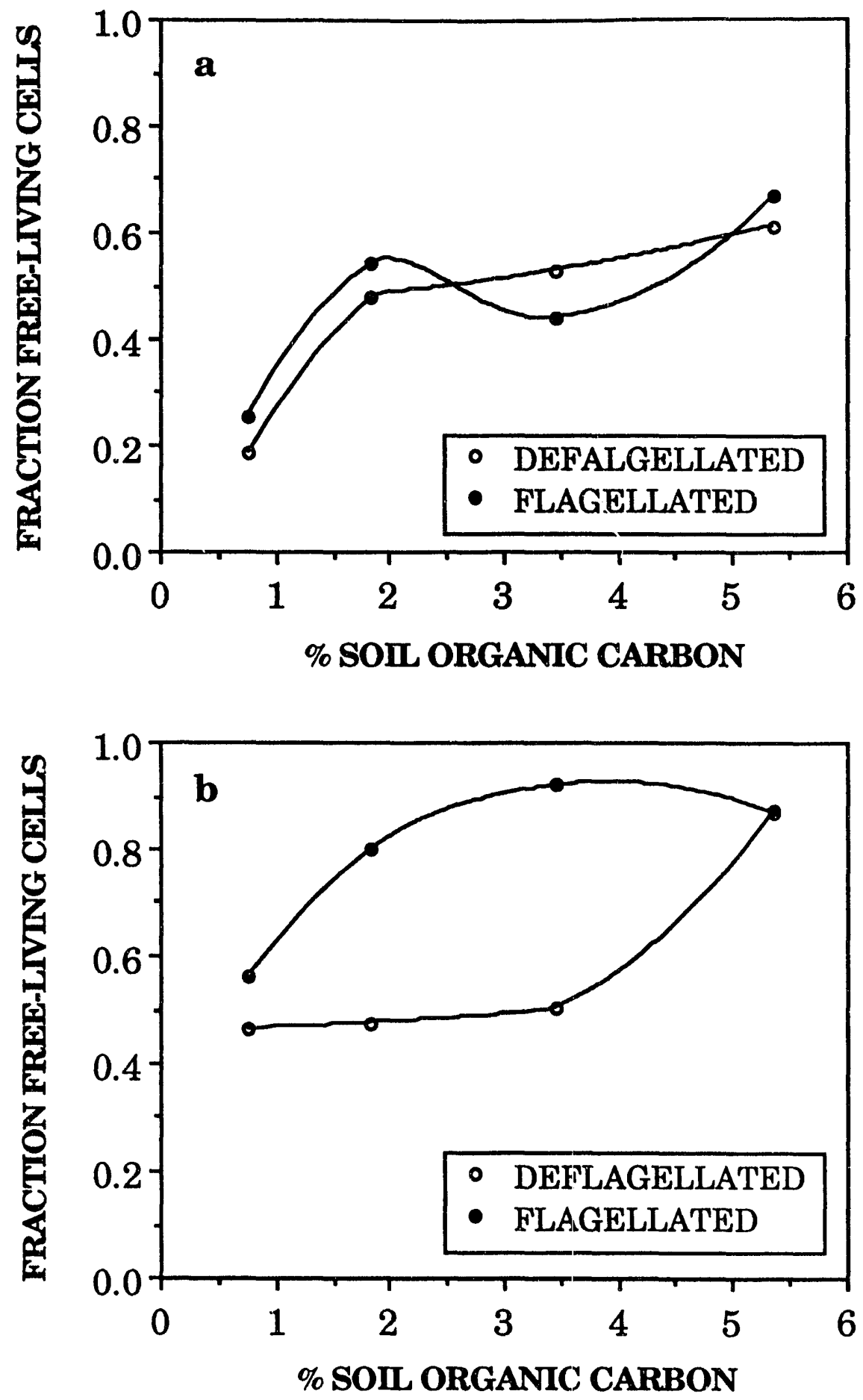

Figure 5. Attachment of flagellated and deflagellated cells of strains 17484 (a) and NP-Alk (b) to four soils $(200 \mathrm{mg} / \mathrm{ml})$ as a function of soil organic carbon content, and in the presence of chloramphenicol (50 $\mathrm{ppm})$. 


\section{TAXIS OF STRAIN 17484 TO CLAY MINERALS}

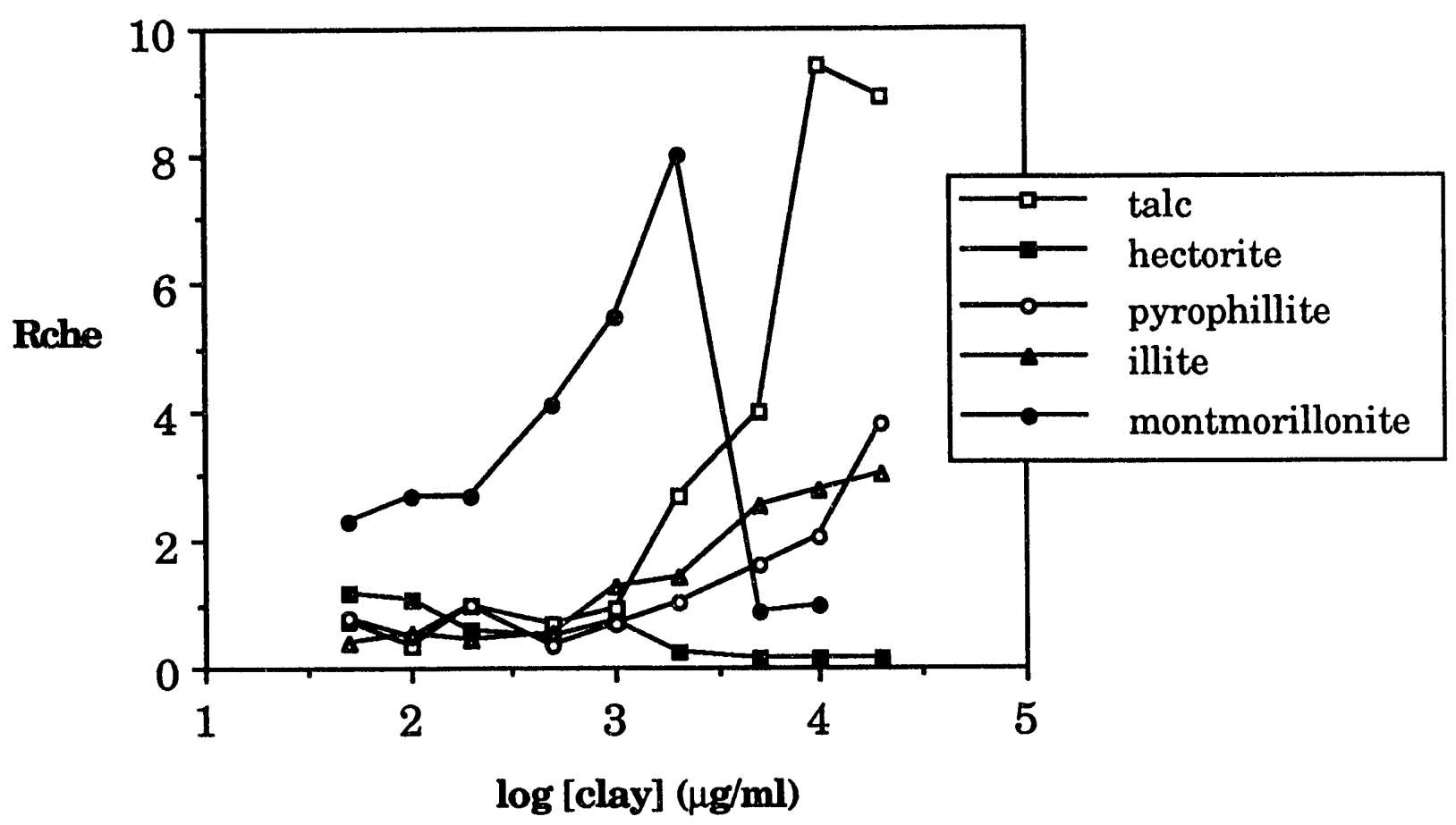

Figure 6. Taxis of strain $17484\left(10^{7} \mathrm{cel} 1 \mathrm{~s} / \mathrm{ml}\right.$ in pool) to various clay minerals as a function of clay concentration (in PBS) after one hour incubations. Rche is the chemotaxis ratio, defined as the number of cells in treatment capillaries divided by the number of cells in control capillaries (PBS). All points represent the means of triplicate capillaries. 

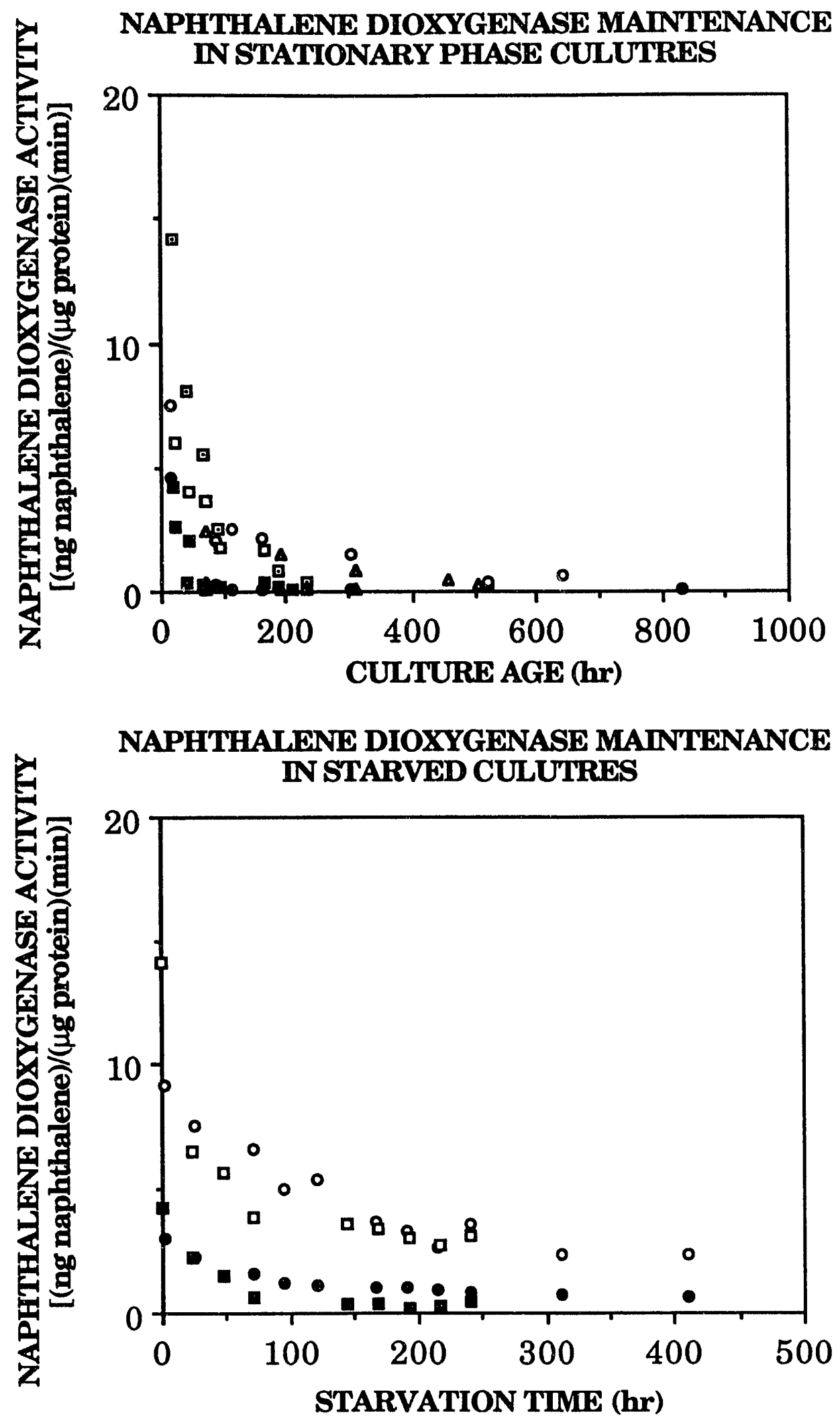

Figure 7. Naphthalene dioxygenase activity of strains 17484 (open symbols) and NP-Alk (solid symbols) as a function of culture age in stationary phase cultures (top panel) or under starvation conditions (bottom pane1) following growth on naphthalene. Different symbols correspond to separate experiments. 

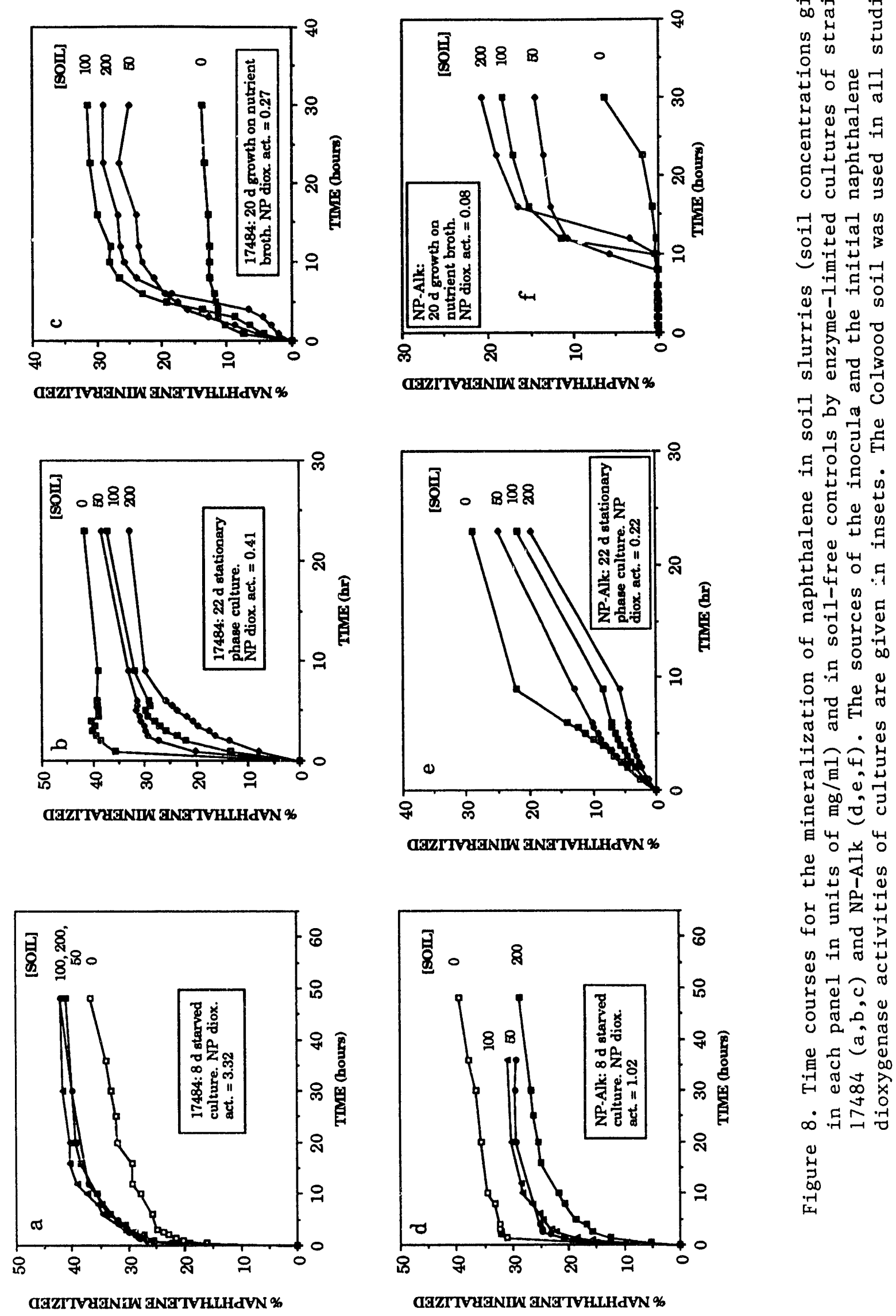


\section{INFLUENCE OF SORPTION ON 2,4-D MINERALIZATION KINE TICS BY STRAIN FB-4}

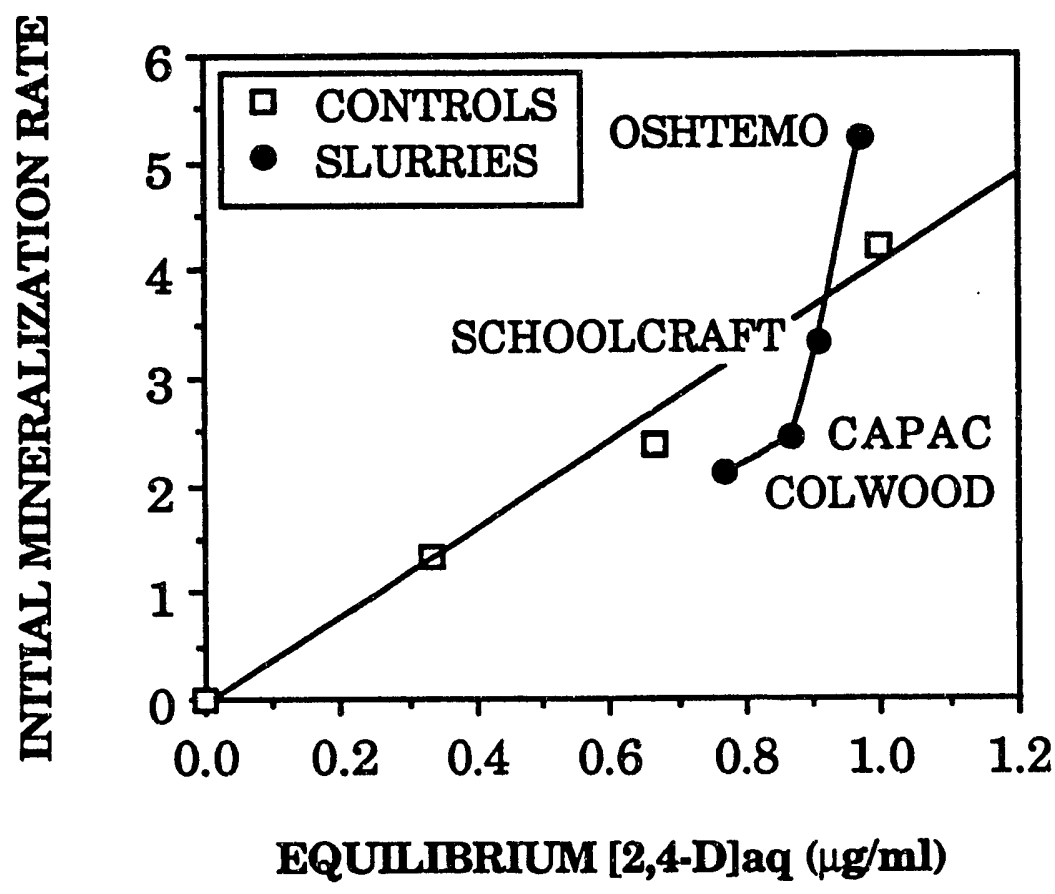

Figure 9. Influence of sorption on the rate of 2,4-D mineralization by Flavobacterium sp. straj.n FB-4 in slurries of four soils $(200 \mathrm{mg} / \mathrm{ml})$ of varying organic carbon contents (solid symbols, see legend to Figure 2 for soil OC contents). Data for soil-free controls are shown as open boxes. 


\section{TABLE 1}

Influence of clay minerals on the rate and extent of naphthalene mineralization by strains 17484 and NP-Alk.

Mineralization rate enhancement* in the presence of

\begin{tabular}{|c|c|c|c|c|}
\hline Organism & Montmorillonite & Pyrophyllite & Hectorite & Talc \\
\hline 17484 & $\begin{array}{l}1.42 \\
(1.04)^{* *}\end{array}$ & $\begin{array}{l}1.00 \\
(1.13)\end{array}$ & $\begin{array}{l}1.33 \\
(1.04)\end{array}$ & $\begin{array}{l}1.62 \\
(1.11)\end{array}$ \\
\hline NP-Alk & $\begin{array}{l}0.89 \\
(0.87)\end{array}$ & $\begin{array}{l}0.80 \\
(C 99)\end{array}$ & $\begin{array}{l}0.93 \\
(0.87)\end{array}$ & $\begin{array}{l}0.80 \\
(0.90)\end{array}$ \\
\hline
\end{tabular}

* Initial mineralization rate in naphthalene-clay suspensions $(2.0 \mathrm{mg}$ clay $\mathrm{ml}-1)$ divided by the rate in clay-free controls.

$* *$ Values in parentheses are the ratios of $\mathrm{v}_{1} / \mathrm{k}$ values (extent of mineralization) in clay suspensions to values in clay-free controls. 


\section{TABLE 2}

Maintenance of naphthalene dioxygenase activity in starved and stationary phase cultures of strains 17484 and NP-Alk. Enzyme half lives determined from first order decay model fits of plots of activity vs. time.

\begin{tabular}{llcc} 
& \multicolumn{3}{c}{ Naphthalene Dioxygenase $\mathrm{t}_{1 / 2}$} \\
Organism & Stationary & Starved & Starved/Stationary \\
\hline 17484 & $43.3 \mathrm{~h}$ & $115.5 \mathrm{~h}$ & 2.7 \\
NP-Alk & $13.1 \mathrm{~h}$ & $69.3 \mathrm{~h}$ & 5.3 \\
17484/NP-Alk & 3.3 & 1.7 &
\end{tabular}



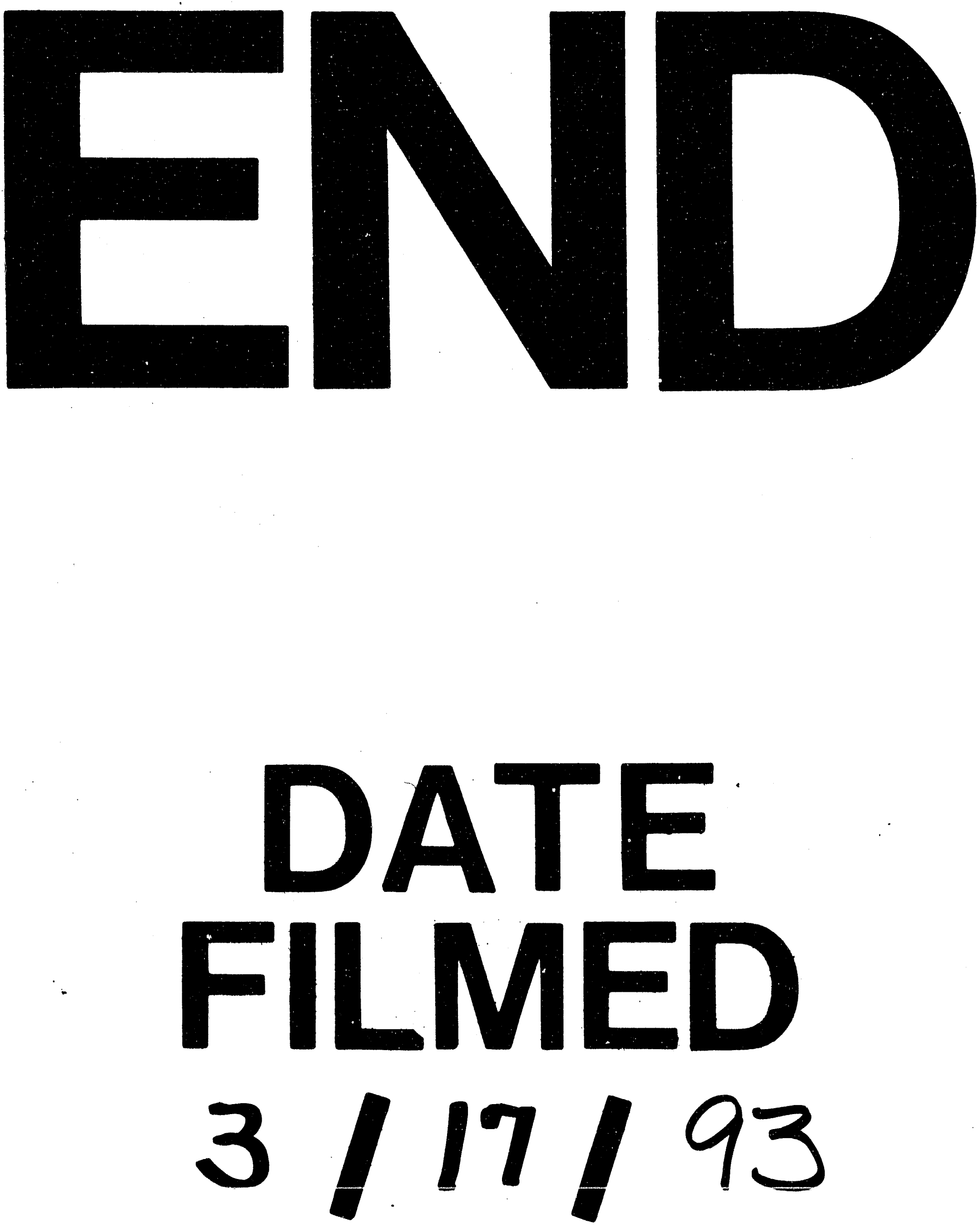
